\title{
An Emotional Study of Product Design: Images of Cleaning Containers
}

\author{
Yi-Hsien Lin (Corresponding Author) \\ Creative Product Design \\ Far East University \\ Tainan, Taiwan \\ Email:yisam0915@yahoo.com.tw
}

\author{
Chen-Yin Liu (2nd Author) \\ Digital Media Design \\ Tzu Hui Institute of Technology \\ Pingtung, Taiwan
}

\author{
Jenn-Yang Lin (3rd Author) \\ Industrial Design \\ National Cheng Kung University \\ Tainan, Taiwan
}

\author{
Shen-Kui Huang (4th Author) \\ Industrial Design \\ National Cheng Kung University \\ Tainan, Taiwan
}

\begin{abstract}
Product design has always been a key in influencing a consumer's desire to purchase a product in a highly competitive market. During the designing process, the designer has to understand how the consumer's senses appeal towards the appearance of a product, and go through numerous researches into the images that most favor the consumer's wishes. Thus, it has been of great importance in the study of marketing how the appearance of a product can cognitively affect a consumer's willingness to purchase a product. The study below is a research using cleaning products as an example, in which it explores the different psychological attitudes purchaser's display in the different image designs of the product.
\end{abstract}

Applying the study of Semantic Differential, this research utilizes ten different images of cleaning containers to explore the connection between the product image and the emotional reaction in purchasing a product. The experiment uses seven emotional keywords such as "sporty", "cute", "simple", "rationale", "technological", "gentle", and "traditional", and attach them separately to the ten images of cleaning product designs

The result concludes square and cylinder bottle designs display emotional keywords that relate to "simple" and "traditional"; cylinder bottle images exemplify emotional keywords such as "simple", "gentle", and "rational"; circular, flat bottles that contract at the bottom display an emotional keyword of "sporty"; symmetrically curved bottles display emotional keywords of "cute" and gentle". Furthermore, the emotional keyword assessment between the designs of square bottles, convex bottles, one-sided concave bottles, and asymmetrical curved bottles seem to display the most significant differences.

Keywords-Product Images; Marketing Stretegy; Semantic Differential

\section{INTRODUCTION}

In recent years, competitive markets have allowed more diverse choices for consumers in selecting their products, motivating the market to search for more innovative and creative ideas. Affective and commercial values have become a key approach from marketers, as well as a product's imagery and visual design, becoming the main influences in a consumer's desire for purchase. Products are now evaluated not only by its function, but its appearance as well, the imagery further impacting the consumer's overall assessment of a product. Thus, the studies into researches conducted by product designers to connect emotionally and resonate visually with the consumer's psychological responses have become a great subject in marketing.

Cognitive fluency results in consumers' decision to respond to familiar product designs and is usually influenced from life experiences, backgrounds, etc. Every design element in a product - the line, shape, colour, texture, etc, can subject the consumer to mentally connect emotional messages between the mind and the object, further solidifying the product image. In conclusion, the design and image of a product can expose and provoke emotional responses from the consumer, and the consumers' familiarity and subconscious connections with the image can lead to a higher desire in consumption.

To further exploit image designs that are consumeroriented, this study samples images of cleaning products from the market, and uses them to better understand the connections between emotional responses and visual images through sematic differences. By investigating the psychological connections between human feelings and bottle shape images, the goal of this study is to categorize the various bottle images to its corresponding emotional reaction. 


\section{LITERATURE}

The main area of this study focuses on the deconstruction and investigation of the consumer's emotional responses to the various cleaning bottle shapes, and follows the methods of "Kansei Engineering" in executing the research. The following analyses are the findings and examinations of the research, including "Cognitions between the consumer and product images" and "Exploration of kansei engineering and related visual concepts".

For the research on various bottle shapes, this study focuses on the six main shapes of product bottles, categorized by Yang Ching-tian (2001). These shapes include prismatic bottles, convex and concave bottles, flattened round bottles, tall bottles, oblique bottles, and, and groove bottle can undergo various transformations based on viewing in different angles and the size of the bottles. He studied consumer' s bottle shape preferences, and found that the most popular shapes included oblique bottles, large concave bottles, large convex bottles, spiraled bottles, and centric protruding bottles (as Figure 1).

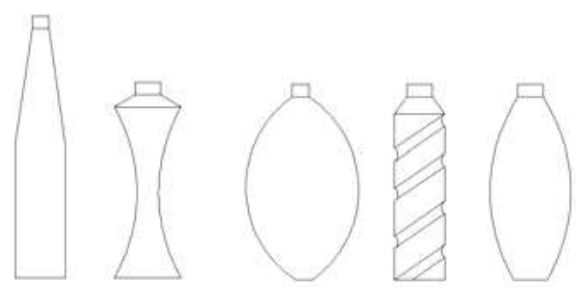

Figure1 The most popular shapes: oblique bottles, large concave bottles, large convex bottles, spiraled bottles, and centric protruding bottles

According to market sales, the visual design of packaging has now become a crucial element in swaying consumer's desires for a product (Prendergast and Pitt, 1996). Packaging is the opening bridge way between a brand and its communication with customers, and under the rising competitive market, the status of product design has now risen to a major role in marketing (Rettie and Brewer, 2000). The main function for packaging has been to safely protect the product and ensure it can be conveniently maneuvered during transport, storage, sales, and usage (Gonzalez, Thorhsbury \& Twede, 2007; Wells et al., 2007; Kuvykaite, 2001). The categorizations of the packaging design elements have widely differed between scholars; Kotler (2003) suggested six main components to consider- size, shape, material, colour, pattern, and brand; while Silayoi \& Speece $(2004,2007)$ proposed two main components - visual elements ( graphics, shape, colour, and size) and informative elements (technical aspects). Silayoi \& Speece (2004) posited that during the consumer's purchasing decision-process, visual elements of a package link to emotional responses, and informative elements link to cognitive responses. Thus, packaging design has now become a significant component in understanding consumer behavior, and this study will further explore the influence of a container's visual elements on consumer's opinions.
"Kansei Engineering" focuses on evolving and improving products and services by translating human emotions and psychological needs to product designs to satisfy consumer desires.

With more versatile and personalized demands on products by consumers, product imagery has become a vital element in affecting purchasing decisions. For this process, Kansei Engineering has provided an outlook on how to better translate consumer needs and feelings onto product designs, creating new products that are consumer-oriented.

Image is a combination of concepts, judgment, preferences, and attitudes towards various objects (Huang Xiting, 2005). Product image is the psychological connection a consumer makes with his or her own feelings when observing a product, and is associated with previous perceived experiences, with visual perception presenting the most noticeable mental links.

\section{RESEARCH METHOD AND PROCESS}

This study uses cleaning product packaging bottles as the object of study, and collects, categorizes, and evaluates sample collections and vocabulary usage for further research and analysis on consumer's emotional responses to product image. The following is the research method and stages of the experiment.

The selected samples are cleaning products on the Taiwanese market with capacity ranging from $450(\mathrm{ml})$ to $750(\mathrm{ml})$. To avoid colour disruption on the image and to allow test groups to focus on the bottle figure, all the sample images used in the experiment were de-saturated. The forty-five sample image bottles can be seen as Figure 2.

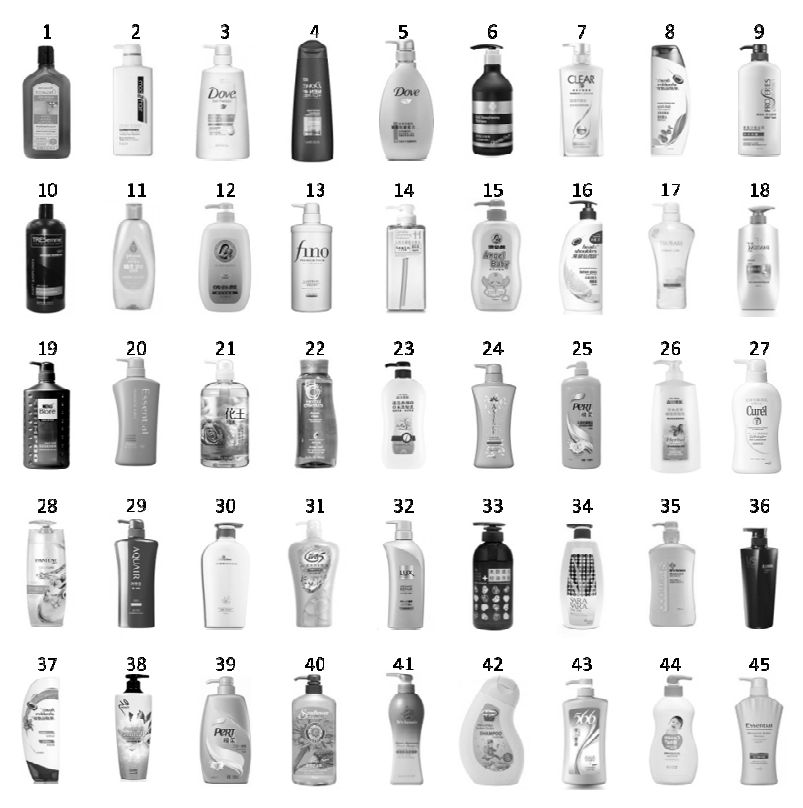

Figure 2 The 45 image bottles 
A total of sixty university students and postgraduates were randomly selected to participate as test subjects, and ranged from $18-30$ years of age as Table 1 .

Table 1 Sample subjects

\begin{tabular}{cl}
\hline $\begin{array}{c}\text { Design background } \\
\text { Male }\end{array}$ & Femal \\
\hline 12 & 19 \\
\hline $\begin{array}{c}\text { None-Design } \\
\text { background } \\
\text { Male }\end{array}$ \\
\hline 16 & Female \\
\hline
\end{tabular}

The experimental samples of this study include perceptual vocabulary and product images. On the origin of the emotional vocabulary, this study is based on the shape of the composite emotional image - based on the shape feature (Zhou Junrui, 2001), the study of "the stratified cluster analysis and calculation of the cumulative number of words" Use the representative of the vocabulary. These emotional vocabularies using for this study can be classified as "sporty", "cute", "simple", "rational", "technological", "gentle", and "traditional".

To establish realistic human emotional responses to the bottle images, all the samples were taken from existing cleaning products on the market. The forty-five samples were then categorized by industrial design students into five shape groups using the KJ Method - "square bottles" , "round bottles", "flattened round bottles", "convex and concave bottles", and "oblique bottles". "Flattened round bottles

" were then branched into two categories - "circular, flat bottles that expanded at the bottom" and "circular, flat bottles that contract at the bottom"; "convex and concave bottles" were branched into four categories - "concave bottles", "convex bottles", "one-sided concave bottles", and "one-sided convex bottles"; "oblique bottles" were branched into two categories - "symmetrical bottles" and " asymmetrical bottles". After the grouping, ten samples were then selected from each category to best represent their visual shape as Figure 3.

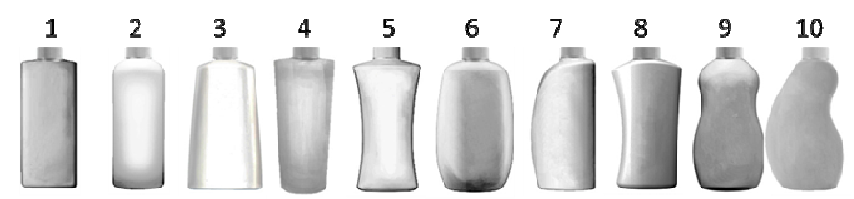

Figure 3 The 10 sample shape
In related researches, studies have proven there were no emotional or cognitive psychological distinctions for the test subjects between being shown the actual bottle sample and an image bottle sample (Lee, S.,1999; Zhang Jiancheng, 2000). Therefore in this study, all the actual bottle samples have been transformed into print image samples to be presented to the test subjects.

In this study, seven perceptual vocabularies and ten container pictures were used to create questionnaires using the Likage scale method (fifth order). After the questionnaire was collected, the perceptual evaluation of the container shape was calculated on the basis of the average. In order to understand the correlation between the container and the emotional vocabularies, the SPSS 12.0 statistical software "Independent sample T test" was used. There is a significant difference in the perceptual vocabulary evaluation of container modeling images between design backgrounds and non-design backgrounds

\section{RESULTS AND ANALYSIS}

The evaluation and standard deviation results of the seven emotional vocabularies reviewed by the sixty test subjects are shown below as Figure 4, with above average 3.5 indicating strong emotional vocabulary responses to bottle sample images.

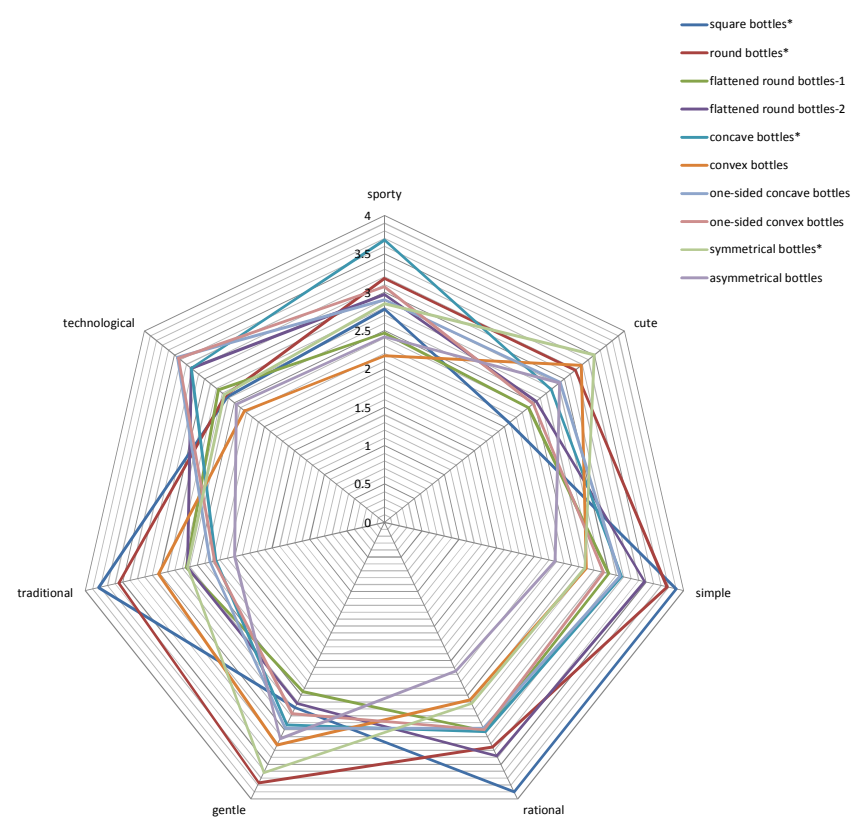

Figure 4. The results of radar chart

From Figure 4, we can see that "square bottle" designs strongly represent " simple", “ rational", and " traditional. "Cylinder bottle" designs relate closely to " simple" , "gentle", and "traditional". Both "simple" and "traditional" are emotional vocabularies equated to "square bottle" and "cylinder bottle" designs. The explanation for this result could be the familiarity tied to organic shapes (squares, circles). As for "circular, flat bottles that contract at 
the bottom" designs, the term "sporty" was most associated with it, possibly due to the light-weight feeling presented by the bottle's design of a smaller lower half. "Symmetrical bottle" designs are represented by emotional terms such as "cute" and "gentle".

This experiment analyzed the designing backgrounds of the testing subjects under the statistic software SPSS 12, to examine if there were any consequences to the results regarding if one had a designing background or not. The analysis showed that 31 test subjects had designing backgrounds, while the other 29 didn't, and that there were significant differences in the emotional responses towards "square bottle", "convex bottle", "one-sided concave bottle", and "asymmetrical curved bottle" designs. However, the other six bottle designs did not have any significant differences in emotional responses regarding the different backgrounds.

Table 2. the comparisons under design background conditions of square bottle and convex bottle

\begin{tabular}{|c|c|c|c|c|c|}
\hline & \multirow{2}{*}{$\begin{array}{c}\text { Design } \\
\text { Background }\end{array}$} & \multicolumn{2}{|c|}{ square bottle } & \multicolumn{2}{|c|}{ convex bottle } \\
\hline & & $\begin{array}{c}\text { Average } \\
\text { (SD) }\end{array}$ & $\begin{array}{c}\mathrm{P} \\
\text { Value }\end{array}$ & $\begin{array}{c}\text { Average } \\
\text { (SD) }\end{array}$ & $\begin{array}{c}\mathrm{P} \\
\text { Value }\end{array}$ \\
\hline \multirow[t]{2}{*}{ sporty } & yes & $\begin{array}{r}2.4516 \\
(1.02758)\end{array}$ & & $\begin{array}{r}1.9355 \\
(.77182)\end{array}$ & \\
\hline & no & $\begin{array}{r}3.1379 \\
(.95335)\end{array}$ & .387 & $\begin{array}{r}2.4138 \\
(.98261)\end{array}$ & $.046^{*}$ \\
\hline \multirow[t]{2}{*}{ cute } & yes & $\begin{array}{r}2.1613 \\
(.96943)\end{array}$ & & $\begin{array}{r}3.4839 \\
(1.02862)\end{array}$ & \\
\hline & no & $\begin{array}{r}2.0000 \\
(.84515)\end{array}$ & .414 & $\begin{array}{r}3.0690 \\
(1.13172)\end{array}$ & .441 \\
\hline \multirow[t]{2}{*}{ simple } & yes & $\begin{array}{r}4.0000 \\
(.68313)\end{array}$ & & $\begin{array}{r}2.5484 \\
(.92516)\end{array}$ & \\
\hline & no & $\begin{array}{r}3.7931 \\
(.81851) \\
\end{array}$ & .084 & $\begin{array}{r}2.8621 \\
(.91512) \\
\end{array}$ & .519 \\
\hline \multirow[t]{2}{*}{ rational } & yes & $\begin{array}{r}4.0968 \\
(.70023)\end{array}$ & & $\begin{array}{r}2.3548 \\
(.91464)\end{array}$ & \\
\hline & no & $\begin{array}{r}3.6897 \\
(.76080) \\
\end{array}$ & .299 & $\begin{array}{r}2.7931 \\
(.86103) \\
\end{array}$ & .752 \\
\hline \multirow[t]{2}{*}{ gentle } & yes & $\begin{array}{r}2.5484 \\
(1.12068 *)\end{array}$ & & $\begin{array}{r}3.4516 \\
(1.12068)\end{array}$ & \\
\hline & no & $\begin{array}{r}2.8276 \\
\left(.80485^{*}\right) \\
\end{array}$ & $.044 *$ & $\begin{array}{r}2.9655 \\
(.98135) \\
\end{array}$ & .226 \\
\hline \multirow[t]{2}{*}{ traditional } & yes & $\begin{array}{r}3.6774 \\
(.74776)\end{array}$ & & $\begin{array}{r}2.7419 \\
(1.12451)\end{array}$ & \\
\hline & no & $\begin{array}{r}3.9655 \\
(.94426)\end{array}$ & .327 & $\begin{array}{r}3.3103 \\
(.84951)\end{array}$ & .062 \\
\hline \multirow[t]{2}{*}{ technological } & yes & $\begin{array}{r}2.8065 \\
(.65418 *)\end{array}$ & & $\begin{array}{r}1.9677 \\
(.65746)\end{array}$ & \\
\hline & no & $\begin{array}{r}2.4138 \\
(1.11858 *)\end{array}$ & $.001 *$ & $\begin{array}{r}2.7241 \\
(.92182)\end{array}$ & $.026^{*}$ \\
\hline
\end{tabular}

$* \mathrm{P}<0.05$
According to Table 2, there was a significant difference between the design background and the non-design background in the " gentle " and " technological " sensibility of the square bottle. And there was a significant difference in the " sporty" and " technological " sensibility of the convex bottle.

Table 3. the comparisons under design background conditions of one-sided concave bottle and asymmetrical curved bottle

\begin{tabular}{|c|c|c|c|c|c|}
\hline & \multirow{2}{*}{$\begin{array}{c}\text { Design } \\
\text { Background }\end{array}$} & \multicolumn{2}{|c|}{$\begin{array}{c}\text { one-sided } \\
\text { concave bottle }\end{array}$} & \multicolumn{2}{|c|}{$\begin{array}{l}\text { asymmetrical } \\
\text { curved bottle }\end{array}$} \\
\hline & & $\begin{array}{l}\text { Average } \\
\text { (SD) }\end{array}$ & $\begin{array}{c}\mathrm{P} \\
\text { Value }\end{array}$ & $\begin{array}{l}\text { Average } \\
\text { (SD) }\end{array}$ & $\begin{array}{c}\mathrm{P} \\
\text { Value }\end{array}$ \\
\hline \multirow[t]{2}{*}{ sporty } & yes & $\begin{array}{r}3.0968 \\
(1.27423)\end{array}$ & & $\begin{array}{r}2.4516 \\
(1.28682)\end{array}$ & \\
\hline & no & $\begin{array}{r}2.6897 \\
(1.00369)\end{array}$ & $.024 *$ & $\begin{array}{r}2.3793 \\
(.97884)\end{array}$ & $.046^{*}$ \\
\hline \multirow[t]{2}{*}{ cute } & yes & $\begin{array}{r}2.8065 \\
(.94585)\end{array}$ & & $\begin{array}{r}3.1613 \\
(1.24088)\end{array}$ & \\
\hline & no & $\begin{array}{r}3.0690 \\
(1.09971)\end{array}$ & .301 & $\begin{array}{r}2.6552 \\
(1.07822)\end{array}$ & .441 \\
\hline \multirow[t]{2}{*}{ simple } & yes & $\begin{array}{r}3.2258 \\
(.92050)\end{array}$ & & $\begin{array}{r}2.0968 \\
(1.01176)\end{array}$ & \\
\hline & no & $\begin{array}{r}3.0690 \\
(.99753)\end{array}$ & .863 & $\begin{array}{r}2.4828 \\
(1.02193)\end{array}$ & .519 \\
\hline \multirow[t]{2}{*}{ rational } & yes & $\begin{array}{r}2.9032 \\
(.83086)\end{array}$ & & $\begin{array}{r}1.7742 \\
(.66881)\end{array}$ & \\
\hline & no & $\begin{array}{r}3.0690 \\
(.88362) \\
\end{array}$ & .677 & $\begin{array}{r}2.5517 \\
(.98511) \\
\end{array}$ & .752 \\
\hline \multirow[t]{2}{*}{ gentle } & yes & $\begin{array}{r}3.0645 \\
(.99785)\end{array}$ & & $\begin{array}{r}3.4194 \\
(1.28515)\end{array}$ & \\
\hline & no & $\begin{array}{r}2.8966 \\
(1.04693) \\
\end{array}$ & .613 & $\begin{array}{r}2.8276 \\
(1.07135) \\
\end{array}$ & .226 \\
\hline \multirow[t]{2}{*}{ traditional } & yes & $\begin{array}{r}2.0968 \\
(.83086)\end{array}$ & & $\begin{array}{r}1.6452 \\
(.60819)\end{array}$ & \\
\hline & no & $\begin{array}{r}2.5862 \\
(1.01831)\end{array}$ & .152 & $\begin{array}{r}2.3793 \\
(.90292)\end{array}$ & .062 \\
\hline \multirow[t]{2}{*}{ technological } & yes & $\begin{array}{r}3.4194 \\
(.95827)\end{array}$ & & $\begin{array}{r}2.1935 \\
(1.10813)\end{array}$ & \\
\hline & no & $\begin{array}{r}3.4828 \\
(1.08958)\end{array}$ & .661 & $\begin{array}{r}2.7586 \\
(1.12298)\end{array}$ & $.026^{*}$ \\
\hline
\end{tabular}

According to Table 3, there was a significant difference between the design background and the non-design background in the " sporty " sensibility of the one-sided concave bottle. And there was a significant difference in the " sporty " and " technological " sensibility of the asymmetrical curved bottle. 


\section{CONCLUSION AND SUGGESTION}

This study employs the visual designs of cleaning supply bottles as the object of study, and by applying methods such as SD method, KJ method, and survey, further research of the connections between human emotional responses and various bottle designs was achieved. Through additional analysis and investigation, the results show that "square bottle" designs correspond strongly with feelings of "clean", "rational", and "traditional". "Cylinder bottle" designs were associated with emotions such as "clean", "gentle", and "rational". "Circular, flat bottles that contract at the bottom" designs were described as "sporty", possibly due to the light-weighted feeling that was presented by the bottle's design of a smaller lower half. "Symmetrical bottle" designs were responded with emotional vocabularies such as "cute", and "gentle", due to it's organic form.

When exposed to test groups that had and didn't have designing backgrounds, the emotional responses towards the designs of the "square bottle", "convex bottle", "one-sided concave bottle", and "asymmetrical curved bottle" were noticeably different. The differences with "square bottle" designs were emotional vocabularies such as "gentle" and "technological"; "convex bottle" designs were met with differences on "sporty" and "technological"; with both "simple" and "traditional" being emotional vocabularies used in "square bottle" and "cylinder' bottle designs. "One-sided concave bottle" designs differentiated on "sporty", and "asymmetrical curved bottle" designs differentiated on "rational". The results of these different responses are evidence that product designs are subjective to the consumer. An explanation for these differences could be that test group with designing backgrounds view the products objectively, and only focus on the product designs; while the test group with no background view the products in their favors.

For future research, it is recommended that colour, material, etc, and other basic designing elements that can affect the emotional responses be considered in the experiment to elevate more noticeable results. The emotional vocabularies can also differentiate between various products, and it is suggested that the selection of terms be further studied. In the making of the survey, it is suggested to apply the Likert scale method to eliminate experiment errors and achieve more accurate psychological responses from the test groups.

\section{REFERENCE}

[1] Carmen Linares, and Alvaro F. Page, , "Kano's model in Kansei Engineering to evaluate subjective real estate consumer preferences," International Journal of Industrial Ergonomics, 41 pp.233-246, 2011.

[2] C.C. Chang, "Factors influencing visual comfort appreciation of the product form of digital cameras," International Journal of Industrial Ergonomics, 38 pp.1007-1016, 2008.

[3] C. Kim, C. Lee, Mark R. Lehto, Myung Hwan Yun, "Evaluation of customer impressions using virtual prototypes in the internet environment," International Journal of Industrial Ergonomics, 41 pp.118-127, 2011.

[4] Gonzalez M. P., Thorhsbury S., \& Twede D., "Packaging as a tool for product development: Communicating value to consumers," Journal of Food Distribution Research, 38 (1), 61-66, 2007.

[5] H.C. Chang, H.H. Lai, Y.M. Chang., "Expression modes used by consumers in conveying desire for product form: A case study of a car," International Journal of Industrial Ergonomics, 36 3-10, 2006.

[6] H.Y. Chen and Y.M. Chang, "Extraction of Product Form Features Critical to Determining Consumers' Perceptions of Product Image Using a Numerical Definition-based Systematic Approach," International Journal of Industrial Ergonomics, 39(1) pp.133-145, 2009.

[7] Kuvykaite, R. Gaminio marketingas. Kaunas: Technologija, 2001.

[8] Kotler, Ph. Marketing management, 9th ed. Upper Saddle River: Prentice-Hall, 2003.

[9] Lee, Seung Hee, Stappers, Pieter J. \& Harada, Akira.,'Extending of Design approach based on Kansei by Dynamic Manipulation of 3D Objects," 4th Asian Design Conference, 1999.

[10] M.S. Huang, H.C. Tsai, and T.H. Huang, "Applying Kansei engineering to industrial machinery trade show booth design," International Journal of Industrial Ergonomics, 41 pp.72-78, 2011.

[11] Prendergast, G. and Pitt, L., "Packaging, marketing, logistics and the environment: are there trade-offs?" International Journal of Physical Distribution \& Logistics Management, 26 (6), 60-72, 1996.

[12] Rettie, R. and Brewer, C., "The verbal and visual components of package design," Journal of Product \& Brand Management, Vol. 9 No. 1, pp. 56-70, 2000.

[13] Salvador Mondragoń, Pedro Company, and Margarita Vergara, "Semantic Differential applied to the evaluation of machine tool design," International Journal of Industrial Ergonomics, 35 pp.10211029, 2005

[14] Silayoi, P., \& Speece, M., "Packaging and purchase decisions: An exploratory study on the impact of involvement level and time pressure," British Food Journal, 106 (8), 607-628, 2004.

[15] Silayoi, P., \& Speece, M., "The importance of packaging attributes: a conjoint analysis approach," European Journal of Marketing, 41 (11/12), 1495-1517, 2007.

[16] Simon Schütte, and Jörgen Eklund, "Design of rocker switches for work-vehicles -an application of Kansei Engineering," Applied Ergonomics, 36 pp. 557-567, 2005.

[17] S.J. Luo, Y.T. Fu, and Pekka Korvenmaa, "A preliminary study of perceptual matching for the evaluation of beverage bottle design," International Journal of Industrial Ergonomics, 42 pp.219-232, 2012.

[18] Nagamachi, "Kansei engineering as a powerful consumer-oriented technology for product development," Applied Ergonomics 33 pp.298294, 2002.

[19] S.J. Luo, Y.T. Fu, and Y.X. Zhou, "Perceptual matching of shape design style between wheel hub and car type," International Journal of Industrial Ergonomics, 42 pp.90-102, 2012.

[20] Shana Smith, and Shih-Hang Fu, "The relationships between automobile head-up display presentation images and drivers' Kansei," Displays, 32 pp.58-68, 2011.

[21] T. Ogawa, Y. Nagai, and M. Ikeda, "An ontological approach to designers' idea explanation style: Towards supporting the sharing of Kansei-ideas in textile design," Advanced Engineering Informatics, 23 pp.157-164,2009. 
[22] Y.C. Lin, H.H. Lai, and C.H. Yeh., "Consumer-oriented product form design based on fuzzy logic: a case study of mobile phones," International Journal of Industrial Ergonomics, 37 pp. 531-543, 2007.

[23] Yuexiang Huang, C.H. Chen, and $\mathrm{Li}$ Pheng Khoo, "Products classification in emotional design using a basic-emotion based semantic differential method," International Journal of Industrial Ergonomics, 42 pp.569-580, 2012.

[24] Yang Qingtian (2001). Investigation on the Hobbies of Packaging Containers. Journal of Art, 69,1-16.

[25] Chen Guoxiang, Guan Xingsheng, Deng Yixin, Zhang Yuming, "Perceptual Engineering - Rationalization of Sensibility", Industrial Design, Vol. 29, No. 1, P14, May 2001

[26] Kobayashi heavy Shun, 1991, shape constitute the psychological, Art Hall published in Taipei.

[27] Song Boqin translation, Lynch, Kevin, 1967, urban imagery, Keelung bookstore, Taipei.

[28] Huang Xiting editor, 2005, concise psychology dictionary, Taipei.

[29] Zhou Junrui, 2001, the formation of composite emotional image - based on the shape characteristics, the National University of success, industrial design master's thesis.

[30] Zhang Jiancheng, 2000, the impact of users on product shape image recognition factors, National University of Transportation, Department of Industrial Engineering and Management doctoral thesis. 